\author{
Andrzej JAESCHKE \\ Uniwersytet Pedagogiczny im. Komisji Edukacji Narodowej, Wydział Nauk Społecznych, \\ Kraków, Polska
}

\title{
Walka o prymat w stanowieniu prawa między Izbą Lordów a Izbą Gmin na początku XX wieku
}

\author{
The Power Struggle between the House of Lords and the House of Commons \\ over the Legislative Supremacy at the Turn of the $20^{\text {th }}$ Century
}

\section{- Abstrakt •}

Na przełomie XIX i XX wieku w parlamencie westminsterskim rozegrał się jeden $\mathrm{z}$ najważniejszych, trwający wiele lat akt konkurencji między obydwoma izbami parlamentu o wpływ na realizację funkcji ustawodawczej w procedurze parlamentarnej. W niniejszym artykule, będącym wynikiem znacznie szerszych studiów nad przekształceniami wewnętrznymi parlamentaryzmu brytyjskiego, przedstawiono społeczne i polityczne tło tej walki toczącej się na forum obydwu izb między dwiema siłami politycznymi: Partią Konserwatywną i Partią Liberalną, wzmocnioną przez taktycznych sojuszników. W tekście starano się przedstawić prawny wynik tego sporu w postaci słynnego Parliament Act 1911, ale także - na podstawie dzisiejszego stanu wiedzy opartego również na zachowanych stenogramach wystąpień parlamentarnych - klimat tego sporu oraz jego społeczne i polityczne tło.

\section{- Abstract •}

At the turn of the $20^{\text {th }}$ century, the Palace of Westminster became the witness to one of the most significant and long-lasting power struggles between the Houses of Parliament regarding the influence of each chamber on the implementation of the legislative function in the parliamentary procedure. This paper, written as part of broader studies on the internal transformations of the British Parliament, presents the social and political background of the supremacy war that was openly waged between two political forces, i.e., the Conservative Party and the Liberal Party, reinforced by their respective tactical allies. An attempt is also made to discuss the legal result of the dispute, which notably came in the form of "The Parliament Act 1911", as well as to trace - based on the current state of knowledge and the preserved shorthand notes and transcripts of parliamentary speeches - the general climate of this conflict and its social and political contours. 
Słowa kluczowe: XIX-XX wiek; Izba Lordów; Izba Gmin; Partia Konserwatywna; Partia Liberalna; parlament brytyjski; reforma Izby Lordów
Keywords: $19-20^{\text {th }}$ centuries; House of Lords; House of Commons; Conservative Party; Liberal Party; British Parliament; reform of the House of Lords

Na początku XX wieku znalazł swój finał pierwszy istotny etap walki o polityczny, ale i ustrojowy prymat pomiędzy Izbą Lordów a Izbą Gmin parlamentu westminsterskiego. Polityczne zabiegi liberalnej większości w Izbie Gmin oraz gabinetu Jego Królewskiej Mości, przy niemałej pomocy monarchy i części liberalnych parów, odniosły skutek. Kilkunastoletnie wysiłki zaowocowały pozbawieniem izby wyższej faktycznego prawa weta. Nie pozwoliły tej izbie na przekształcenie się w czynnik blokujący działalność ustawodawczą ,tamtej izby” oraz uniemożliwiający przez konserwatywną większość izby wyższej reformatorskie działania liberalnej egzekutywy, wspieranej przez progresywnie nastawioną większość w Izbie Gmin.

Do ostatniego dziesięciolecia XIX wieku obserwowano swoistą koabitację w materii kompetencji ustawodawczych między obydwoma izbami. Ustalone już w XV wieku i potwierdzone w wieku XVII zasady kształtowania ustawodawstwa finansowego były generalnie respektowane. Za panowania Henryka IV monopol na zgłaszanie projektów ustaw finansowych wywalczyła sobie Izba Gmin. Dotyczyło to również projektów ustaw podatkowych. Izba wyższa pozbawiona została także prawa do wprowadzenia poprawek. Ten fakt podkreślił badacz tej epoki: „W istocie Izba Gmin rozszerzyła swój przywilej, odmawiając Izbie Lordów prawa do wprowadzenia zmian do projektów finansowych" (Mckenzie, 1968, s. 70). Na polityczne motywacje królewskiej zgody wskazywał Jerzy Z. Kędzierski: „Gdy król zwrócił się z żądaniem do Izby Gmin, ażeby zatwierdziła subsydium uchwalone przez Izbę Lordów, odpowiedź brzmiała, że jest to naruszenie przywilejów Izby. Kompromis, jaki ostatecznie osiągnięto, polegał na zatwierdzeniu bieżących subsydiów w zamian za życzenie monarchy, aby w przyszłości przedstawiano mu uchwały, petycje już uzgodnione przez obie izby. W ten sposób powstał precedens, że inicjatywa w uchwałach skarbowych należy do Izby Gmin” (Kędzierski, 1986, s. 502). Fakt ten niósł za sobą doniosłe polityczne skutki. Bez zgody Izby Gmin bowiem jakikolwiek ruch monarchy w kwestiach finansów państwowych byłby niemożliwy. Oznaczało to wydatne pomnożenie siły izby niższej. Polski badacz tej problematyki pisał: „Właściwa jednak siła parlamentu leżała w jego uprawnieniach w dziedzinie skarbowości” (Koranyi, t. 4, 1967, s. 191). Tę siłę uzyskała Izba Gmin.

Do sprawy tej powrócono w drugiej połowie XVII wieku. W latach 1671 i 1678 jeszcze raz przypomniano, że Izba Lordów nie ma nie tylko prawa do zgłaszania 
projektów ustaw finansowych, ale i prawa do dokonywania jakichkolwiek zmian w projektach tych ustaw tworzonych przez Izbę Gmin. Członkowie Izby Lordów mogli taki projekt albo w całości przyjąć, albo w całości odrzucić. Ten stan rzeczy nie był kontestowany przez następnych sto kilkadziesiąt lat. Generalnie w tych czasach trudno doszukiwać się zbyt wielu przykładów wyraźnego politycznego konfliktu nie tylko na tle procedury ustawodawczej w sferze finansów, ale także procedury ustawodawczej w ogóle. Działalność ustawodawcza obydwu izb polegała na współpracy wynikającej z zasadniczej tożsamości interesów politycznych i ekonomicznych ówczesnej elity władzy. Wywodziła się ona z tego samego kręgu arystokracji ziemskiej, a potem pieniądza. Obie izby powiązane były również związkami rodzinnymi, a także relacjami związanymi z szeroko rozpowszechnioną nieoficjalną instytucją patronatu (Jaeschke, 2013, s. 254-260). Koabitacji tej służyło też średniowieczne prawo wyborcze, redukujące czynne prawo wyborcze do niewielkiej 220-tysięcznej grupy mężczyzn osiągających dochody z ziemi (Sobolewski, 1977, s. 71). Tworzyli oni ekskluzywny klub polityczny (Grzybowski, 1946, s. 16-18).

Badacze ustroju Wielkiej Brytanii wskazują jedynie na trzy przypadki, w których poglądy obydwu izb różniły się w diametralny sposób, skutkując kryzysem we wzajemnych relacjach. W 1713 roku księżniczka Anna politycznym szantażem w postaci groźby powołania nowych parów zmusiła Izbę Lordów do zaakceptowania wynegocjowanych przez jej rząd, wspierany przez Izbę Gmin, warunków pokoju w Utrechcie (Bryant, 2014, s. 117). W roku 1832 „premier Grey przekonał Wilhelma IV do poparcia reformy prawa i matematycznego przełamania kontestującej ten projekt większości w Izbie Lordów” (Lang, 1999, s. 129). Zagrożona swoistą „bombą atomową” w postaci zastosowania precedensu z 1713 roku, izba wyższa zaakceptowała uchwalony przez Izbę Gmin projekt stanowiący nowe prawo wyborcze. Wreszcie w 1860 roku doszło do konfliktu między obydwoma izbami na tle forsowanej przez Izbę Gmin i premiera Williama Gladstone’a ustawy skarbowej obniżającej opłatę stemplową od gazet. Znaczna jej wysokość podwyższała cenę gazet i zawężała dostęp coraz szerszej - potencjalnie - grupy czytelników do informacji. Ostatecznie udało się osiągnąć kompromis. Izba Lordów poparła to rozwiązanie w zamian za wprowadzenie obniżki tego podatku do projektu przyszłorocznego budżetu (Trevelyan, 1965, s. 835). Te trzy wyjątki zdawały się potwierdzać regułę: tożsamość ideowa i programowa, zgoda co do zasadniczych celów politycznych dwóch izb parlamentu, rządu i monarchy skutkowała konstatacją arystokraty w każdym calu, czwartego earla Clarendon i barona Hyde: „Celem istnienia Izby Lordów jest uzupełnić to, co izba niższa pominęła, i naprawiać błędy, które występują w jej pracach” (Smith, 1992, s. 125). Opisywał on stan rzeczywisty. Konser- 
watywne rządy wspierane przez konserwatywną większość w Izbie Gmin oraz Izbie Lordów gwarantowały generalnie harmonijną współpracę w ramach konserwatywnej elity władzy.

Ten stan rzeczy musiał ulec zmianie wskutek wprowadzenia kolejnych reform prawa wyborczego. W ich wyniku do elity władzy weszły grupy polityków liberalnych, a potem inni, związani z reformistycznym socjalizmem. Kwestią czasu było przełamanie faktycznego monopolu na sprawowanie władzy przez zwolenników koncepcji konserwatywnych poprzez powstanie większości parlamentarnej o antykonserwatywnym, postępowym obliczu ideowym. Wtedy musiało stać się to, co trafnie przewidywał wcześniej premier Rosebury w liście do królowej Wiktorii. Wskazywał w nim, że dopóki władzę wykonawczą będą sprawowali członkowie Partii Konserwatywnej, konserwatywna większość w Izbie Lordów będzie spolegliwa wobec zamiarów rządu. Jeżeli jednak władza wykonawcza przejdzie w ręce ugrupowania liberalnego, to wtedy Izba Lordów stanie się opozycją wobec takiego rządu. Sam doświadczył takiej polityki większości Izby Wyższej. Parowie odrzucili lansowany przez niego projekt ustawy dotyczącej nadania autonomii politycznej Irlandii. Był to już drugi projekt liberałów w tej sprawie. Początek XX wieku nie przyniósł tu większych zmian. W roku 1905 premier Henry Campbell-Bannerman pominął procedury parlamentarne $\mathrm{w}$ rozwiązaniu palącego problemu statusu Transwalu. Działając zgodnie z prawem i zwyczajem i mając akceptację monarchy, nadał samorząd tej części Afryki i stworzył tym samym dogodne warunki do zakończenia konfliktu militarnego w południowej Afryce. Decyzja ta, a może raczej wprowadzenie jej „tylnymi drzwiami”, spotkała się z ostrą krytyką Izby Lordów, ale nie oznaczało to jeszcze głębokiego kryzysu. Kolejny rozdział tego sporu rozpoczęły wybory parlamentarne w roku 1906. Przyniosły one zdecydowane zwycięstwo Partii Liberalnej, a premier Campbell-Bannerman przystąpił do realizacji ambitnego programu reform w sferze edukacji i spraw socjalnych. W pierwszej kolejności poddano procedurze ustawodawczej reformę oświaty. Po długich deliberacjach w parlamencie stosowna ustawa została uchwalona, ale tylko dlatego, że rząd przyjął wiele poprawek z Izby Lordów, które po części wypaczały jej sens. Jeszcze gorszy los spotkał ustawodawcze zamierzenia rządu dotyczące ograniczenia powszechnej w Wielkiej Brytanii plagi pijaństwa. Ten projekt ustawy naruszał zbyt wiele interesów, a w czołówce jej przeciwników była Izba Lordów. Projekt ten upadł w głosowaniu w Izbie Lordów stosunkiem głosów 272 do 96, przy akompaniamencie złośliwości kierowanych $\mathrm{z}$ ław lordowskich pod adresem rządu (Lowe, 1998, s. 267-268). Podobnie nie zyskał akceptacji większości parów projekt ustawy reformującej prawo wyborcze w kierunku likwidacji głosowania pluralistycznego, a także projekt nowej ustawy edukacyjnej z 1908 roku i cztery projekty ustaw 
agrarnych. Tylko w jednym przypadku pod ostrzałem opinii publicznej, zarzucającej Izbie Lordów celową obstrukcję parlamentarną paraliżującą ustawodawstwo państwowe, parowie się ugięli, dostrzegając spadające notowania całej izby. Ostatecznie w roku 1909 do prawnego obrotu weszła ustawa wprowadzająca powszechny system ubezpieczenia emerytalnego. Należy dodać, że ostateczny kształt ustawy odbiegał od pierwowzoru i był wynikiem kompromisu z parami.

W odpowiedzi na te wydarzenia, już od końca XIX wieku, kolejne gabinety liberalne starały się zapobiegać obstrukcyjnej polityce realizowanej przez Izbę Lordów. W roku 1883 komisja parlamentarna przedstawiła zalecenia, które miały przyspieszyć bieg prac ustawodawczych i ograniczyć możliwości ich hamowania przez izbę wyższą. Pierwszy minister przypomniał o nich w 1897 roku, przeprowadzając przez Izbę Gmin stosowną uchwałę. Podkreślano w niej, że Izba Lordów powinna mieć ograniczone możliwości wprowadzania poprawek do uchwalonych już przez izbę niższą projektów oraz odrzucania tych projektów. Postulowano powoływanie wspólnej komisji mającej rozstrzygać kontrowersje. Gdyby po trzech takich bezskutecznych próbach szukania kompromisu nie doszło do niego i projekt trzykrotnie wracałby do Izby Gmin - ustawa miała stać się prawem (Danel, 2014, s. 107). Ta propozycja została odrzucona przez większość parów. Byli jednak - choć w zdecydowanej mniejszości - członkowie Izby Lordów dostrzegający konieczność rewizji takiej polityki i reformy samej izby. Być może poważnie traktowali ostrzeżenie sformułowane kilkadziesiąt lat wcześniej przez Waltera Bagehota - finansistę i bystrego obserwatora tendencji politycznych, który pisał: „Niebezpieczeństwo związane z Izbą Lordów polega na tym, że może nigdy nie zostanie zreformowana [...]. Może ona podobnie jak kiedyś Korona stracić prawo veta. Jeśli większość z jej członków będzie zaniedbywać swoje obowiązki, a wszyscy członkowie pochodzić z tej samej klasy społecznej - i to niekoniecznie tej najlepszej - jeśli jej drzwi będą zamknięte przed wielkimi talentami bez rodzinnych korzeni oraz umiejętności nowszymi niż te nabyte przed tysiącami lat, władza tej izby będzie z roku na rok słabnąć, aż w końcu całkiem zniknie, tak jak zniknęła w większości władza królewska - a nikt nie wie, jak to się stało. Niebezpieczeństwem czyhającym na Izbę Lordów nie jest to, że zostanie zamordowana, ale to, że zacznie obumierać, nie jej zniesienie, lecz chylenie się ku upadkowi” (Danel, 2014, s. 95-97). Podzielali ten pogląd niektórzy bardziej progresywni politycy z Izby Lordów. Uformowali oni wewnątrz tej izby nieformalny zespół lobbujący za podjęciem próby zreformowania tej instytucji. Na jego czele stanął wybitny polityk związany z ruchem liberalnym, były premier oraz autor biografii kilku polityków brytyjskich, Archibald Philip Primrose Piąty earl Rosebury (Parker, 2013, s. 80). Grupa ta ukonstytuowała się $\mathrm{w}$ formie komisji i przedstawiła końcowy raport ze swoich prac. Sugerowano w nim 
zmiany daleko idące. Planowano wprowadzenie trzech kategorii parów. Do pierwszej z nich proponowano zaliczyć parów wybieranych na jedną kadencję przez dotychczasowych lordów. Grupę drugą mieli stanowić parowie dziedziczni „dotychczasowego typu". Wreszcie grupa trzecia to posiadający tytuł para byli ministrowie oraz inne osoby piastujące w przeszłości ważne stanowiska państwowe. Te miały przydać Izbie Lordów kompetencji. Ale i ta sprawa na skutek oporu większości nie miała dalszego ciągu.

Tymczasem zmieniał się powoli polityczny klimat wokół Izby Lordów. Nasilały się głosy krytyki. Przypominano prerogatywy monarsze dotyczące mianowania na wniosek premiera - nowych parów, choćby spośród członków gwardii królewskiej, do czego często zachęcano. Miało to doprowadzić do przełamania konserwatywnej większości w Izbie Lordów. Dla arystokratów była to potwarz. Rozwijała się ofensywa propagandowa, a prasa stawała się coraz potężniejszym orężem politycznym. Na łamach poczytnych periodyków i prasy codziennej formułowano zjadliwe uwagi. Z kręgów prasy liberalnej płynęły oskarżenia o zasklepieniu się członków konserwatywnej większości Izby Lordów na obronie własnych przywilejów. Ciągle przypominano skandale związane z kupczeniem tytułami lordowskimi w zamian za przysługi wyświadczane działaczom partyjnym. Nie były to oskarżenia wyssane z palca, ten proceder był bowiem obecny w kulturze politycznej Wielkiej Brytanii przynajmniej od czasów odrzucenia przez Izbę Lordów projektu ustawy mającej zwalczać pijaństwo. Wypominano parom hołdowanie co najmniej wątpliwej moralności. Podkreślano, że wielu parów, zamiast myśleć o interesach państwa i zwykłych obywateli, myśli jedynie o zabezpieczeniu swojej pozycji. Szczególnie zjadliwy w tej krytyce był na początku wieku Joseph Chamberlain, czołowy polityk lewicowego skrzydła Partii Liberalnej i wytrawny gracz polityczny. Ten opisywał parów jako grupę ludzi bez zasad, niczego nieprodukujących i żerujących na pracy pozostałej ciężko pracującej części społeczeństwa. Wskazywał, że swój status zawdzięczają nie własnej pracy, ale łasce królewskiej. Wtórował mu wybitny przywódca frakcji liberalnej w Izbie Gmin. Jego wypowiedzi przeszły do annałów parlamentarnej retoryki. David Lloyd George był politykiem nietuzinkowym, który nie darzył - oględnie rzecz ujmując - parów estymą. Parowie odwzajemniali mu się tym samym, dodając do tego poczucie wyższości zaprawione ledwo maskowaną pogardą. Był samoukiem o wielkiej politycznej intuicji. Wdarł się do elity władzy jako syn walijskiego nauczyciela i wychowanek szwagra swojego ojca, z zawodu szewca. „Dowcip miał przy tym zabójczy, pewność siebie wielką, z pogardą do klas posiadających się nie krył. Obok Disraelego to niewątpliwie druga niezwykła postać wśród brytyjskich mężów stanu” (Kędzierski, 1986, s. 383). Pisał i mówił o lordach jako przypadkowej grupie kilkuset osób wybranych spośród rzeszy innych 
bezrobotnych, a w arystokracji widział ser, który im starszy, tym bardziej jest zepsuty. Za nim szli inni. Niektórzy posuwali się bardzo daleko, żądając rozwiązań definitywnych. Proponowali pozbawić Izbę Lordów prawa weta w stosunku do projektów Izby Gmin (Kędzierski, 1986, s. 378). Nic więc dziwnego, że wybuch niczym niemaskowanego starcia o ustawodawcze kompetencje był tylko kwestią czasu.

Kolejny akt walki o ustawodawczą supremację rozpoczął się z chwilą przejścia na polityczną emeryturę szefa liberalnego gabinetu JKM Henry'ego Campbella-Bannermana. Funkcję premiera objął pięćdziesięcioczteroletni polityk Partii Liberalnej Herbert Henry Asquith. Nowym kanclerzem skarbu został natomiast wzmiankowany już zwolennik reform i ograniczenia roli Izby Gmin David Lloyd George. Po kilku miesiącach poświęconych przygotowaniu ostatecznego kształtu refom i zwiększenia wydatków na zbrojenia kanclerz skarbu nadał nowy polityczny impuls walce z Izbą Lordów, przedstawiając - jak go określał badacz epoki - „zapierający dech w piersiach pierwszy budżet” (Bryant, 2014, s. 135). Był on niewątpliwie zapierający dech ze względu na swoje koszty. Pierwsza grupa wydatków była obiektywnie konieczna z uwagi na bezpieczeństwo państwa. Kilka lat wcześniej cesarskie Niemcy rozpoczęły realizację zakrojonego na szeroką skalę programu zbrojeń morskich, których realizacja mogła zagrozić brytyjskiej supremacji na morzach. Przewaga na morzach była warunkiem sine qua non bezpieczeństwa tego wyspiarskiego państwa, uzależnionego od dostaw surowców i żywności drogą morską. Aby zachować istniejącą przewagę Zjednoczonego Królestwa, stan marynarki wojennej trzeba było szybko powiększyć. Należało wybudować osiem wielkich okrętów wojennych i zdobyć na to środki. Nie można było ich znaleźć w dotychczasowych dochodach budżetowych. Gospodarka brytyjska znajdowała się w kryzysie i wpływy do budżetu malały. Trzeba było także znaleźć środki na zapowiedziany w manifeście wyborczym program refom społecznych, które miały objąć uboższą część społeczeństwa. Podkreślając powagę sytuacji, kanclerz skarbu nazwał swój budżet narodowym. „Potrzeba mi - oznajmił - pieniędzy na budowę nowych pancerników, na wydatki wojenne, na emerytury dla starców. Zażądam ich od bogatych" (Maurois, 1957, s. 530). Stwierdzenie to wywołało wśród najbogatszych prawdziwy szok. Podobnie zareagowała ich konserwatywna polityczna ekspozytura w Izbie Lordów. Projekt budżetu nie był zrównoważony. Po stronie nadzwyczajnych wydatków były sumy zaplanowane na wybudowanie ośmiu pancerników. Spore sumy miały pochłonąć wydatki na ochronę środowiska i poprawę infrastruktury drogowej. Dochody miały zostać uszczuplone poprzez wprowadzenie ulg podatkowych dla podatników zarabiających poniżej 500 funtów rocznie oraz obniżenie podatku dochodowego o 10 funtów na każde dziecko w rodzinie (Kędzierski, 1986, s. 383). Do zrównoważenia budżetu zabrakło 16 milionów funtów. Gabinet poszukał do- 
datkowych wpływów poprzez wprowadzenie nowych podatków i podwyższenie niektórych do tej pory obowiązujących. „W projekcie dochodów budżetowych konstatował znawca problematyki - położono nacisk na podatkowanie środków trwałych wielkich właścicieli ziemskich. Realizowano w ten sposób dawno zgłaszany przez radykalnych liberałów postulat opodatkowania bogaczy. I tak od dochodu poniżej 3000 funtów podatek miał wynosić jeden szyling od funta, ale od dochodów powyżej 5000 funtów już dwa. Dochód powyżej 5000 funtów skutkował zapłaceniem swoistego super podatku wynoszącego 6 szylingów od funta. Z dzisiejszej perspektywy podatek ten wydaje się raczej łagodny, ale w roku 1909 uważany był przez wielu za zdecydowanie wygórowany" (Lyon, 2003, s. 375).

Nie koniec na tym. W projekcie budżetu przewidziano podwyższenie podatku spadkowego, a także wprowadzenie nowego podatku gruntowego. Jego wysokość miała zależeć „od aktualnego szacunku wartości gruntów i nieruchomości, a płatnym przy każdej tego rodzaju transakcji - kupnie i sprzedaży (przede wszystkim domów mieszkalnych i placów budowlanych). Do tego dochodził nowy podatek od eksploatacji minerałów" (Kędzierski, 1986, s. 383). Propozycje te wywołały w izbie wyższej polityczną burzę. Podnosząc kwestie ideologiczne, konserwatyści szermowali hasłem o zamachu rządu na święte prawo własności. Jesienią 1909 roku rozpoczęła się debata nad „budżetem ludu” w Izbie Gmin. Zainicjował ją kanclerz skarbu jako jego autor. Dla dzisiejszego obserwatora wystąpień parlamentarnych wydaje się to niemożliwe, ale Lloyd George przemawiał cztery i pół godziny i zajął 554 miejsce siedzące, kompletnie fizycznie i psychicznie wyczerpany. Kończąc, apelował, że najwyższy czas położyć kres ubóstwu i że nie można skąpić środków na ten cel. Wystąpienie tego polityka rozpoczęło debatę trwającą 72 dni i noce. W Izbie Gmin przeprowadzono 554 głosowania. Ostatecznie na początku listopada projekt budżetu został przyjęty przez Izbę Gmin przeważającą większością głosów. Równolegle z dyskusją w Izbie Gmin wypowiadali się półoficjalnie wybitni przedstawiciele konserwatywnej frakcji w Izbie Lordów. Nie były to wypowiedzi sympatyczne. I tak lord Arthur James Balfour, prominentny konserwatysta, konstatował, że „ustawa finansowa z 1909 roku jest mściwa, niesprawiedliwa i nie trzymająca się zasad oraz szkodliwa dla produktywności kraju” (Bryant, 2014, s. 137). Lord Edward Clarson grzmiał o początku końca prawa własności. Dla lorda Rosebery budżet miał być „inkwizytorski, tyrański i socjalistyczny” (Bryant, 2014, s. 137). Dostało się też zwolennikom budżetu. Tenże sam lord nadmieniał, że chętnie by zobaczył Lloyda George’a i Churchilla pośród dwudziestu par psów, a Henry Manners, ósmy książę Rutland, określił cały rząd jako pirackich obdartusów w otoczeniu kilku świetnych arystokratów. Wydawało się, że jest to zwyczajna, choć ostra polityczna retoryka, jednak bez konsekwencji w postaci odrzucenia 
projektu budżetu określanego mianem ludowego. Odpowiadali im czołowi liberałowie w Izbie Gmin. Lloyd George zarzucał konserwatystom zamykanie oczu na interes narodowy, a ten - jak mówił - nakazywał zwiększenie wydatków na rozbudowę floty. Odnotowywał, że wprawdzie konserwatyści nie są przeciwni budowie nowych pancerników, ale chcieliby to uczynić kosztem innych, niżej sytuowanych grup społeczeństwa. Konserwatyści - mówił - zachowują się ,jak prawdziwe pasożyty żerujące na trudzie pracodawców i pracowników” (Lyon, 2003, s. 374).

Okazało się jednak, że wypowiedzi te dopiero zapowiadały nadciągającą polityczną burzę w postaci najgłębszego kryzysu w relacjach między gabinetem i wspierającą go większością w Izbie Gmin a konserwatywną większością w Izbie Lordów. W pięć dni po uchwaleniu budżetu przez Izbę Gmin lider konserwatystów w tej izbie zawiadomił, że izba nie wyrazi zgody na projekt budżetu, dopóki nie zostanie on poddany ocenie wyborców podczas nowych wyborów. „To było szalone - napisał badacz problematyki brytyjskiego parlamentaryzmu - bowiem powszechnie przewidywano, że wybory wygrają liberałowie i zostaną wprowadzone prawa ograniczające Izbę Lordów" (Bryant, 2014, s. 137).

Tymczasem 11 listopada 1909 roku rozpoczęła się oficjalna debata na projektem ludowego budżetu w izbie wyższej. Zgodnie z ustalonym zwyczajem pierwszy wystąpił przewodniczący Izby Lordów Robert Milner, książę Crewe. Ku zdumieniu części parów nie wyraził sprzeciwu wobec procedowania ustawy, negując tym samym prawo tej izby do łamania finansowych przywilejów Izby Gmin. Odpowiedział mu lider konserwatystów wśród parów, czwarty markiz Landsdowne. Był to niekończący się potok oskarżeń pod adresem Izby Gmin. „To, co zamierzam powiedzieć, jest proste. Projekt budżetu jest bardzo poważnym aktem prawnym. Dlatego powinien uzyskać aprobatę Izby Lordów. Izba Lordów reprezentuje mieszkańców kraju i to oni powinni zabrać głos. A bez tego projekt budżetu nie może stać się prawem. I takie jest stanowisko większości. A czego domagają się szlachetni lordowie strony przeciwnej? Oczekują, że projekt budżetu, jaki przyjdzie z Izby Gmin, będzie przyjęty bez sprzeciwu lub przy niewielkim proteście. Oliver Cromwell stworzył tak zwaną małą Izbę Lordów wyłącznie w jednym celu - ochrony ludu Anglii przed straszną arbitralnością Izby Gmin, arbitralnością najbardziej odrażająca, jaka istniała na świecie. Myślę, że możemy wykryć objawy strasznej arbitralności w działaniach Izby Gmin , które w tej chwili dyskutujemy. Z całą powagą - moi Lordowie - mamy prawo zapytać, kto te praktyki powstrzyma. Jeżeli można wymusić przyjęcie ustawy o wycenie nieruchomości, wymusić przyjęcie ustawy budżetowej nakładającej podatki na cały kraj” (Lang, 1999, s. 147). W dalszej części swojego wystąpienia markiz Landsdowne ostro polemizował z argumentami gabinetu. W jego opinii projekt budżetu nie nosi charakteru ustawy fi- 
nansowej, gdyż sami jego autorzy opisywali go jako instrument daleko idącej zmiany politycznej i społecznej. Potem przeszedł do końcowych ocen. Zaproponowane w projekcie podatki uznał za „odrażające z natury” (Lang, 1999, s. 147), a sam podatek od gruntu za „drapieżny”. W konkluzji podkreślał: „Moi Lordowie, odrzucając ten projekt, powiecie, że nie jest to projekt, co do którego nie możecie udzielić zgody, dopóki nie zostanie złożone przez ludność tego kraju, że pragną tego prawa” (Lang, 1999, s. 147). Do tej wypowiedzi odniósł się kanclerz skarbu. Wskazywał, że stanowisko Izby Lordów będzie miało wpływ nie tylko na ten konkretny casus, ale może mieć bardziej dalekosiężne skutki. Mówił: „Teraz, moi lordowie, czcigodny markiz Landsdowne założył, że Izba Lordów ma bezwzględne i niewątpliwe prawo, aby odrzucić projekt budżetu. Jeśli się zapytam, czy może to zrobić zgodnie z prawem, odpowiem - niezaprzeczalnie tak. Ale jeśli zapytam, czy może to zrobić zgodnie z konstytucją, mówię - moim zdaniem - nie. [...] Panowie, sprawa ta nie dotyczy tylko bieżącej sytuacji. To nie tylko dyskusja o tym, według jakich praw kraj jest rządzony. Dotyczy ona również tego, jak będzie w przyszłości. Dlatego musimy szukać rozwiązań przyszłościowych, [...] i modyfikować prawo w stosunku do zmieniających się potrzeb” (Lang, 1999, s. 147). Podczas debaty, trwającej następnych sześć dni, znakomita większość parów zdawała się podzielać poglądy markiza. Poparł go m.in. Forest Browne, biskup Bristolu, a jednocześnie konserwatysta i naukowiec archeolog. Podtrzymał żądanie skierowane do gabinetu, aby ten podał się do dymisji, i zwrócił się do monarchy o rozpisanie wyborów. Nazwał je swoistą formą „,konsultacji z ludem”. Były też wypowiedzi bardziej emocjonalne. Książę Marlborough uważał, że projekt budżetu jest wynikiem nienawiści gabinetu do parów i ma mściwie wyrównywać bliżej nienazwane rachunki. Najbardziej mściwymi mieli być Lloyd George oraz Churchill. Niektórzy zajmowali bardziej ostrożne stanowisko. Lord Rosebury wprawdzie nie pozostawił na projekcie budżetu suchej nitki, określając go jako wart pogardy, niemniej zauważał, że gra nie toczy się tylko o budżet, a więc nie warto stawiać na szali przyszłości Izby Lordów i stwarzać wrażenie, że los izby zależy od jej stanowiska w sprawie budżetu. Mówiąc to, miał na uwadze nasilające się wśród radykalnych liberałów głosy wskazujące na konieczność zlikwidowania tej izby parlamentu westminsterskiego. Dlatego też oświadczył, że podczas głosowania wstrzyma się od głosu. Stenogram odnotował również głosy wzywające do poparcia projektu z politycznych przyczyn. Biskup Gore dostrzegał w projekcie realizację sprawiedliwej idei stopniowego rozkładania obciążeń podatkowych, tak aby można było realizować godną poparcia politykę socjalną gabinetu. Z kolei urodzony w Holandii par sympatyzujący z liberałami Donald McKay, jedenasty lord Reay, ostrzegał kolegów lordów przed głosowaniem za odrzuceniem projektu, ponieważ: „oligarchie są rzadko niszczone, zaś częściej 
popełniają samobójstwo" (Bryant, 2014, s. 139). W tym samym duchu wypowiadał się biskup Persival. Podkreślał, że oczywiście można odwołać się do wyborców, licząc na to, że liberałowie wybory przegrają i liberalny projekt budżetu zejdzie z politycznej agendy. Mówił, że są to błędne rachuby, a w ostateczności klęskę poniesie Izba Lordów. Sytuacja jest bowiem taka, że „nigdy więcej w tym kraju podstawowe swobody narodu nie będą zagrożone przez żadną uprzywilejowaną klasę” (Bryant, 2014, s. 139). Jednak głosy tego typu, nawołujące do zachowania politycznego rozsądku, tonęły w morzu konserwatywnej demagogii, pełnej poczucia wyższości i urażonej godności.

29 listopada 1909 roku wpływowy członek Izby Lordów wicehrabia John Morley poinformował, że członkowie tej izby nie poprą projektu budżetu. Dzień później przeprowadzono procedurę głosowania. Stosunkiem głosów 350 do 75 Izba Lordów odrzuciła projekt budżetu. Reakcja premiera Asquitha była natychmiastowa. Zarzucił Izbie Lordów pogwałcenie norm konstytucyjnych oraz uzurpację praw należących do Izby Gmin.

Wybitny brytyjski historyk o konserwatywnych poglądach uznał tę decyzję izby wyższej za największy błąd taktyczny w nowoczesnej polityce (Trevelyan, 1965, s. 835). Jak konstatował w swoim dziele o historii Anglii: „Ta nowa interpretacja funkcji konstytucyjnych dziedzicznej Izby Lordów w sprawach finansowych była równoznaczna uzurpowaniu sobie prawa do narzucania wyborów powszechnych, kiedykolwiek izbie tej to się spodoba. [...] W przyszłości zatem Izba Gmin, która nie spodoba się Izbie Lordów, mogła być rozwiązywana wedle ich woli. [...] Wiek dwudziesty nie był odpowiednią porą do wysuwania przez dziedziczną izbę pretensji do takiej władzy, jakiej nie sprawowała nawet w arystokratycznym XVIII wieku" (Trevelyan, 1965, s. 835).

Na początku grudnia 1909 roku monarcha na wniosek premiera rozwiązał Izbę Gmin. Termin wyborów wyznaczono na styczeń 1910 roku. W kampanii wyborczej konserwatyści szermowali hasłem o zamachu rządu na święte prawo własności. Jednak taka argumentacja była puszczana mimo uszu przez przeważającą część opinii publicznej. Dlatego konserwatywni parowie wytoczyli argument natury formalnoprawnej. Argumentowali, że „klauzule szacunkowe dla nowego podatku gruntowego zawartego w budżecie nie są odpowiednie dla zamieszczenia w projekcie finansowym, a więc taki budżet nie może rościć sobie pretensji do zwyczajnego, niekwestionowanego uchwalenia przez Izbę (Trevelyan, 1965, s. 835). Innymi słowy, w tej sprawie ostatnie słowo należy do parów. Tymi dwoma hasłami posługiwali się konserwatyści podczas kampanii wyborczej. Ale hasło liberałów, zawierające się w pytaniu: „kto ma rządzić - panowie czy lud?”, było niewątpliwie bardziej nośne społecznie. Partia Liberalna wykorzystywała je szeroko nie tylko 
podczas mitingów i w drukach ulotnych, ale i w propagandzie wizualnej (Bryant, 2014, s. 137). Obserwatorzy ówczesnej sceny politycznej przypuszczali, że liberałowie odniosą przytłaczające zwycięstwo, samą kampanię wyborczą uznali za niebyt interesującą. Jak to często bywa, eksperci przepowiadający wynik wyborów nie do końca mieli rację. Frekwencja była bardzo wysoka - o ponad milion uprawnionych do głosowania większa niż w poprzednich wyborach w 1906 roku - 6667400 . Liberałowie zdobyli 274 mandaty i utracili poprzednią przytłaczającą większość. Konserwatyści wraz ze sprzymierzonymi z nimi członkami partii liberalnych unionistów - 272. Członkowie Partii Pracy obsadzili 40 miejsc, a irlandzcy nacjonaliści - 82 (Rallings, Thrasher, 2007, s. 18).

Aby sprawować władzę wykonawczą, liberałowie zawarli sojusz parlamentarny z posłami z Partii Pracy oraz z irlandzkimi nacjonalistami. Cena jednak była wysoka. Irlandczycy udzielili poparcia w zamian za obietnicę przeprowadzenia ustawy o autonomii dla Irlandii. Obietnica ta rozwiązywała problem dużej większości w izbie niższej, ale jednocześnie otwierała nowy front walki z Izbą Lordów. Konserwatywna większość w tej izbie nie dopuszczała nawet do siebie myśli o autonomii dla Irlandii, traktując posłów z ugrupowania nacjonalistycznego jako zdrajców. W tej nowej sytuacji gabinetowi pozostawało jedno rozwiązanie - podjęcie próby przełamania oporu Izby Lordów poprzez wprowadzenie do tej izby takiej liczby nowych parów, która mogłaby przełamać konserwatywną większość i zapewnić liberałom przychylność tej izby. Dlatego też pierwszy minister poprosił króla o mianowanie trzystu nowych parów z listy przygotowanej przez egzekutywę. Jednak odpowiedź monarchy była negatywna: „prywatny sekretarz króla poinformował poufnie prywatnego sekretarza premiera H.H. Asquitha, że ten nie będzie mógł znaleźć usprawiedliwienia dla powołania tylu nowych lordów do czasu nowych wyborów" (Bryant, 2014, s. 140).

W tej sytuacji premier postanowił zmienić taktykę. Porzucił pomysł dalszego nacisku na monarchę na rzecz nowej inicjatywy ustawodawczej. W imieniu gabinetu wprowadził pod obrady Izby Gmin projekt trzech uchwał. Miały one w sposób radykalny ograniczyć kompetencje Izby Lordów w toku prac ustawodawczych. Projekt pierwszej uchwały zakładał pozbawienie Izby Lordów prawa do odrzucania ustaw budżetowych. Tu weto izby wyższej przestałoby istnieć. Projekt drugi stanowił, że w przypadku innych projektów ustaw Izba Lordów miała posiadać jedynie prawo weta zawieszającego. Jeżeli jednak projekt zostałby przyjęty trzykrotnie przez izbę niższą, to wtedy wchodziłby w życie mimo oporu Izby Lordów. Wreszcie projekt trzeci dotyczył skrócenia kadencji Izby Gmin z siedmiu do pięciu lat.

Obrady w Izbie Gmin nad tymi trzema projektami rozpoczęły się 14 kwietnia od wystąpienia pierwszego ministra uzasadniającego konieczność zaakceptowania 
tych propozycji. Oczywiście Izba Lordów była świadoma dalekosiężnych konsekwencji przyjęcia dwóch pierwszych uchwał. Lordowie zasięgali opinii wybitnych prawników konstytucjonalistów, którzy zgodnie podkreślali, że ich przyjęcie doprowadzi do stopniowej marginalizacji izby wyższej. Dlatego też większość członków Izby Lordów dojrzała do kompromisu. Parowie zaproponowali pewne reformy, które uznano za konieczne. Miały one polegać na stopniowym zlikwidowaniu instytucji lorda dziedzicznego. Izba miała pochodzić częściowo z nominacji partyjnej. Pięćdziesięciu lordów miała wskazać Partia Konserwatywna i pięćdziesięciu liberałowie (Kędzierski, 1986, s. 387).

Propozycja procedowania trzech projektów uchwał ograniczających status ustrojowy Izby Lordów spowodowała, że projekt budżetu przestał być przedmiotem sporu. Stawka była znacznie wyższa niż jednostkowy akt prawny. Chodziło o przyszły status ustrojowy „odwiecznej izby”. Dlatego też budżet narodowy został ponownie uchwalony przez Izbę Gmin 27 kwietnia 1907 roku, a dzień później uchwaliła go Izba Lordów.

Dyskusja nad propozycjami reformy funkcjonowania Izby Lordów była w pełnym toku, kiedy 6 maja 1910 roku zmarł król Edward VII i na tron wstąpił Jerzy V. W przeciwieństwie do swojego ojca nie posiadał on większego doświadczenia politycznego. Fakt ten postanowił wykorzystać premier Herbert Henry Asquith i przyspieszyć konsultacje w sprawie reformy izby wyższej. Kontynuował zatem próby zbudowania szerszej koalicji na rzecz wzmiankowanej reformy, którą miały tworzyć największe ugrupowania parlamentarne. Sądząc z faktu, że w rozmowach uczestniczyli prominentni przedstawiciele zarówno liberałów, jak i konserwatystów, były szanse na uzyskanie porozumienia. Konsultacje te toczyły się raczej niespiesznie i w konfidencji. Trwały cały 1910 rok. Brał w nich udział w charakterze mediatora zarówno Edward VII, jak i potem Jerzy V. Jednak próby królewskich mediacji nie zakończyły się powodzeniem z powodu - jak pisał eufemistycznie George Macaulay Trevelyan - „zbyt gorącej temperatury” (Trevelyan, 1965, s. 837). Panowała ona szczególnie między konserwatystami a ugrupowaniem irlandzkich unionistów. Stąd też pierwotne zamierzenie, aby zbudować rząd szerokiej koalicji na rzecz reformy, pozostało jedynie w sferze nieziszczonych planów.

Wobec braku szans na stworzenie rządu mającego stabilną większość parlamentarną, pozostawał pewny plan awaryjny. Pierwszy minister zwrócił się do monarchy o rozwiązanie Izby Gmin i rozpisanie nowych wyborów. Miały to być drugie wybory w tym samym roku. Odbyły się one w grudniu 1910 roku i nie zmieniły zasadniczo krajobrazu politycznego w niższej izbie parlamentu. Partia Liberalna obsadziła 272 miejsca, a Partia Konserwatywna o jedno miejsce mniej. Partia Pracy nieznacznie zwiększyła swój stan posiadania, nacjonaliści zaś stracili jedno 
miejsce (Rallings, Thrasher, 2007, s. 19). W tym stanie rzeczy istniała teoretyczna możliwość powstania koalicji konserwatystów, labourzystów i nacjonalistów z premierem Arthurem Balfourem - prominentnym konserwatystą - na czele. Jednakże konserwatyści nie byli w stanie przełamać politycznej niechęci do Partii Pracy i nienawiści do partii irlandzkich nacjonalistów. Tych określali konsekwentnie mianem zdrajców. Otworzyło to drogę do powołania gabinetu koalicyjnego z liberałami na czele, a także do politycznego kompromisu w sprawie ustawy reformującej procedury ustawodawcze w Izbie Lordów. Procedura ustawodawcza w Izbie Gmin rozpoczęła się 27 lutego 1911 roku od debaty w Izbie Gmin, gdzie liberałowie przedstawili nieco zmodyfikowany - w porównaniu z poprzednim - projekt ustawy. Atmosfera obrad była bardzo gorąca. Dziennikarze opisujący obrady donosili o silnym wzburzeniu targającym mówcami, o okrzykach, w których oskarżano politycznych oponentów o zdradę. Ale był to już spektakl obliczony na użytek opinii publicznej, ponieważ stosunek sił w izbie był oczywisty. W pierwszym czytaniu głosowanie okazało się pomyślne dla gabinetu. W drugim, decydującym głosowaniu większością 368 do 243 głosów Izba Gmin przyjęła projekt rządowy. Wreszcie 15 maja 1911 roku, po prawie trzymiesięcznym procedowaniu, doszło do ostatecznego głosowania. Ustawa przeszła stosunkiem głosów 362 do 241 (Bryant, 2014, s. 142). Nosiła ona tytuł Parliament Act 1911.

Osiem dni później rozpoczęła się debata w Izbie Lordów. Wydawało się, że stanowisko większości Izby Lordów pozostało niezmienne. Sformułował je lord Halsbury, zwracając się do kolegów: „Byłem w polityce ponad 60 lat i nigdy nie byłem świadkiem takiej próby ubezwłasnowolnienia drugiej Izby w celu uzyskania najwyższej władzy nie tyle dla Izby Gmin [...], ale dla zwiększenia siły rządu i wspierającego go klubu politycznego. To nie kwestia podziału partyjnego, ale kwestia życia czy śmierci konstytucji” (Lang, 1999, s. 147). Tego wystąpienia z uwagą wysłuchał pierwszy minister i odpowiedział na nie, przemawiając w Izbie Gmin. Oskarżał konserwatystów w Izbie Lordów, że to właśnie oni kierują się interesem partyjnym, a nie wyższymi zasadami, na które powołują się tak często. „Jest oczywiste - mówił - że całe to gadanie o obowiązku lub prawie Izby Lordów wpływania na kwestie finansowe jest tylko wynikiem tego, że liberałowie mają większość w Izbie Gmin. Kiedy rządzili konserwatyści, obrona tych kompetencji nigdy nie istniała” (Lang, 1999, s. 148).

Konserwatyści w Izbie Lordów podczas procedowania zastosowali starą, wielokrotnie wypróbowaną już taktykę. Przy pomocy sztuczek proceduralnych starali się maksymalnie odwlec ostateczne głosowanie. Zgłaszali więc niekończący się ciąg poprawek o szczegółowym charakterze. Ta praca toczyła się od końca maja, przez cały czerwiec, do połowy lipca. Poirytowany tą parlamentarną obstrukcją 
premier zdecydował się na podjęcie rzadko do tej pory stosowanego w praktyce parlamentarnej kroku. W liście do monarchy wskazywał, że taktyka Izby Lordów ma destrukcyjny charakter i - wobec tego - nie powinna być dłużej tolerowana. Zwrócił się do Jerzego V, aby ten wykorzystał swoją prerogatywę do mianowania grupy nowych lordów. O tym zamiarze poinformowano lidera Partii Konserwatywnej Arthura Balfoura oraz przywódcę konserwatystów w izbie wyższej markiza Landsdowne’a. Groźba skierowana pod adresem Izby Lordów - jak się wydawało - osiągnęła zamierzony skutek. Konserwatywni parowie zaniepokojeni możliwością pojawienia się w ich izbie nowych kilkuset kolegów (o nie najlepszym drzewie genealogicznym lub nawet bez niego) ugięli się przed wolą egzekutywy i uchwalili projekt ustawy. Jednak z poprawkami. Dlatego też projekt powrócił do Izby Gmin w celu przedyskutowania propozycji parów. Przebieg obrad był nieoczekiwany. Propozycje poprawek parów i stosunek rządu do nich chciał zaprezentować premier. Nie było mu dane nawet zacząć tej prezentacji. Konserwatyści w Izbie Gmin zgotowali mu burzliwe przyjęcie. Miotano pod jego adresem nieparlamentarne epitety, gwizdano, skandowano, że jest zdrajcą. Oskarżano o sprzymierzenie się z posłami nacjonalistów irlandzkich. Gdy tumult na chwilę ustał, premier zdążył wypowiedzieć kilka zdań. Polityczna awantura wróciła ze zdwojoną siłą. Wreszcie spiker Izby Gmin „z powodu poważnych zaburzeń” zamknął obrady Izby” (Bryant, 2014, s. 142-143). Sprawy się ważyły, a obie strony sporu czekały na błąd przeciwnika. Popełnił go lider konserwatystów w Izbie Gmin. Krytykując znany już powszechnie wniosek premiera do króla o mianowanie nowych parów, wykazał się pychą i kompleksem wyższości wobec monarchy. Było to polityczne samobójstwo. Znieważył króla, wskazując, że nie posiada on niezbędnego doświadczenia, aby dokonać odpowiedzialnych nominacji nowych parów. Wypowiedź tę natychmiast nagłośnili i wykorzystali politycznie liberałowie. Ujmując się za honorem monarszym, oskarżyli Balfoura o obrazę królewskiego majestatu, a to było dla opinii publicznej szanującej monarchę nie do przyjęcia.

W środę 9 sierpnia 1911 roku w godzinach popołudniowych parowie rozpoczęli obrady. Atmosfera w dalszym ciągu nie była przychylna przyjęciu stanowiska Izby Gmin, ale parowie uświadomili sobie, że błędu Balfoura już nie da się naprawić. $\mathrm{Na}$ spokojny przebieg obrad wpłynęło też - być może - swoiste zmęczenie wielomiesięcznym procedowaniem ciągle tej samej kwestii. Ton dyskusji nadawali tym razem zwolennicy politycznej kapitulacji. I tak lord Morley proponował, aby w ogóle nie podejmować debaty na ten temat. Mówił, że byłby to krok nieprzemyślany. Nie rozwinął wszakże tej myśli. Biskup Westminsteru przytomnie konstatował, że kolejne odrzucenie projektu niczego nie zmieni. Powróci on do Izby Gmin, a następnie, w niezmienionej postaci, do Izby Lordów. Lord Ribbelsdale wskazywał, że 
próby zachowania godności są warte uznania, ale dalsza obstrukcja nie może być politycznie owocna. Lord Curzon wykazał się pragmatyzmem: „Nie da się uciec od faktu, że projekt przejdzie. Działania lorda Halsbury i jego przyjaciół mogą opóźnić jego ostateczne przyjęcie o kilka dni lub kilka tygodni, ale nie mogą zapobiec jego ostatecznemu przyjęciu. Doszliśmy do punktu, w którym należy przyznać, że praktyczne możliwości oporu zostały wyczerpane. Przypuśćmy, że swoimi głosami pokonamy rząd, a ten doprowadzi do kreowania lordów. Co dobrego zrobisz dla siebie, dla partii, dla kraju, dla sprawy? W głębi serca nie chciałbym być pokonany przez rząd JKM. [...] Narażałoby to nas na śmieszność. Dlatego też należy cofnąć się - mówię to do parów po tej konserwatywnej stronie Izby" (Lang, 1999, s. 148). Jednak takie apele nie trafiały wszystkim do przekonania. W dyskusji często brały górę emocje. Lord Salisbury konstatował: „Czy będziemy w większości, czy będziemy w mniejszości, nikt tego nie zauważy. Ale jedno jest pewne, że w annałach tego roku przejdzie do historii to, że pewna liczba ważnych lordowskich mości głosowała zgodnie z ich [tzn. członkami większości Izby Gmin - przyp. A.J.] opiniami” (Bryant, 2014, s. 144). Dla lorda Andrew Willoughby de Broke’a sama myśl, że mógłby głosować tak jak posłowie koalicji rządowej w Izbie Gmin, była nie do przyjęcia. Podkreślał, że posłowie nie mają prawa do reprezentowania narodu, w słowach pogardliwych kwestionował ich prawo do zajmowania miejsc w Izbie Gmin. Grzmiał podczas dyskusji, że nawet tuzin wyborów nie przekona go do zmiany stanowiska. Słowa te bardziej pasowały do retoryki parlamentarnej XV, a nie XX wieku. Jednak dla wielu czas się zatrzymał. Analizując przebieg debaty, można pokusić się o konstatację dotyczącą motywów tego werbalnego oporu. Były one zapewne różne - zawiedzione ambicje, ukrywane często kompleksy wyższości, wreszcie często nieskrywane arystokratyczne poczucie intelektualnej i moralnej przewagi nad członkami „tamtej izby”. Ale wielu zapewne sądziło, że zapowiedź powołania przez monarchę nowych parów jest tylko elementem politycznego szantażu gabinetu wobec większości Izby Lordów. Takie wypowiedzi miały świadczyć o determinacji i nieprzejednanej postawie oraz - paradoksalnie - wzmocnić wahania monarchy w kwestii realizacji jego prerogatywy. Jednak takie rachuby - o ile faktycznie były brane pod uwagę - okazały się błędne. Gra została zakończona, kiedy 9 sierpnia upoważniony przez monarchę przedstawiciel pałacu Buckingham przekazał wiadomość, że następnego dnia Jego Królewska Mość przystąpi do mianowania nowych parów. Oczywiście procedura ta nie zostanie zapoczątkowana, o ile Izba Lordów przyjmie projekt Parliament Act 1911. 10 sierpnia, podczas posiedzenia Izby Lordów, lord Morley odczytał przygotowane wcześniej oświadczenie: „Gdyby projekt został odrzucony tego wieczora, Jego Wysokość wyraziłby zgodę na pozytywne rozpatrzenie wniosku o powołanie takiej liczby nowych parów, aby przy jakiej- 
kolwiek kombinacji Izba Lordów nie mogła odrzucić po raz kolejny tego projektu" (Bryant, 2014, s. 144). Lordowie otrzymali także informację, że premier ma już przygotowaną listę 250 kandydatów do Izby Lordów i że ma wielką determinację, aby przekazać ją monarsze. To spowodowało, że w głosowaniu Izba Lordów przyjęła projekt ustawy, chociaż z dużą liczbą głosów „przeciw” i lordów absentujących to głosowanie. Wszystko to odbywało się w atmosferze niepewności co do wyniku. Przeciw było 144 parów, ale głosów „za” było zdecydowanie więcej. Istnienie Izby Lordów zostało zachowane, lecz niektóre istotne kompetencje już nie. Prymat Izby Gmin w procesie ustawodawczym został utrwalony i odtąd stał się niepodważalny.

W preambule do ustawy ustawodawca oświadczał, że w przyszłości Izba Lordów będzie powoływana nie na zasadzie dziedziczenia miejsc, ale w powszechnym głosowaniu. Wskazywano jednocześnie, że sprawa ta będzie procedowana dopiero w dalszej perspektywie. Równocześnie zapowiadano, że w przyszłej ustawie określi się również kompetencje tej odmienionej izby wyższej, ale że będą one ograniczone. Dodajmy, że gabinet premiera Asquitha powołał specjalną komisję mającą określić procedurę wybierania członków Izby Lordów. Jednakże jej praca nigdy nie zaowocowała sformułowaniem konkretnych wniosków. Do czasu nowego aktu prawnego ustawodawca wprowadzał daleko idące ograniczenia prerogatyw Izby Lordów w zakresie procedowania ustaw o charakterze finansowym.

Ograniczono również uprawnienia Izby Lordów w procesie ustawodawczym dotyczącym ustaw o charakterze publicznym. Izba ta mogła dwa razy odrzucić projekt tej samej ustawy publicznej, przyjęty w dwóch kolejnych sesjach parlamentu, a przekazany jej najpóźniej na miesiąc przed zakończeniem sesji. Po wyczerpaniu tej procedury projekt miał trafić do monarchy w celu udzielenia jego sankcji. Spiker Izby Gmin był zobowiązany do dołączenia oświadczenia, że dochowano wymogów procedury właściwej temu tokowi postępowania.

Jak pisał Konstanty Grzybowski, trafnie przedstawiając konsekwencje zmian: „Od uchwalenia tej ustawy każdy uchwalony przez Izbę Gmin projekt ustawy w materii finansowej staje się ustawą w ciągu miesiąca od przesłania projektu Izbie Gmin. W ten sposób uchwała Izby Lordów w sprawach finansowych jest jakby niewiążącą opinią dla Izby Gmin. Odnośnie innych ustaw ograniczono prawo Izby Lordów do weta zawieszającego; jeśli Izba Gmin w ciągu trzech kolejnych sesji ponowi uchwalenie projektu ustawy zmienionego lub odrzuconego przez Izbę Lordów - projekt ten staje się ustawą" (Grzybowski, 1946, s. 28). Tak więc Izba Lordów straciła realne instrumenty ingerowania w treść ustawodawstwa forsowanego przez posiadający większość parlamentarną gabinet. Tylko w dwóch wypadkach do wejścia w życie ustawy potrzebna była zgoda obydwu izb. Pierwszy to przedłużenie kadencji parlamentu, czyli Izby Gmin. Drugi to przyjmowanie ustaw prywat- 
nych, czyli takich, które dotyczyły praw lub obowiązków indywidualnych osób fizycznych bądź prawnych. Od tego czasu - jak trafnie skonstatował polski badacz problematyki Izby Lordów - lordom pozostało w zasadzie tylko opóźnianie legislacji, ewentualnie wprowadzanie do niej poprawek, które mogły znaleźć uznanie w Izbie Gmin, choć nie musiały. Mimo to Izba Lordów tylko w wyjątkowych okolicznościach wykorzystała pełny cykl trzech kolejnych sesji parlamentu do procedowania projektu ustawy. Dotyczyło to projektów o dużym ciężarze gatunkowym, co wszakże oznaczało, że izba wyższa nie zrezygnowała do końca z rywalizacji z izbą niższą czy gabinetem. Pierwszy przypadek dotyczył projektu ustawy o autonomii dla Irlandii. Nieprzychylna temu projektowi konserwatywna większość Izby Lordów zastosowała weto. Doprowadziło to do przedłużenia procedury aż do 1914 roku. Dopiero wtedy król mógł podpisać ustawę. Jednak na skutek wybuchu wojny światowej ustawa nie weszła w życie. Stało się to dopiero w 1921 roku po - jak pisał George Macaulay Trevelyan - „serii straszliwych wydarzeń” (Trevelyan, 1965, s. 825). Podobnie przedłużono procedowanie kolejnego projektu ustawy poświęconej odebraniu Kościołowi walijskiemu statusu instytucji państwowej. Procedowano nad nią od 1912 roku, zawieszona na czas wojny weszła w życie w 1920 roku. Podobnie wlokła się procedura parlamentarna projektu ustawy o abstynencji. Na skutek oporu Izby Lordów weszła ona w życie dopiero po uwzględnieniu lordowskich poprawek w 1913 roku.

Ostatnim projektem ustawy, który wzbudził wielkie kontrowersje wśród większości Izby Gmin i konserwatystów w Izbie Lordów, był projekt ustawy reformującej prawo wyborcze poprzez likwidację głosowania pluralistycznego. „Właściciele sklepów, oberż, biur itp. mieli dwa głosy w wyborach - jeden w miejscu zamieszkania, drugi w miejscu pracy, oczywiście jeśli były to miejsca różne” (Kędzierski, 1986, s. 824). Po raz pierwszy - o czym wspomniano - sprawa ta stanęła na forum parlamentu w 1906 roku. Odrzuciła ją Izba Lordów. Siedem lat później sytuacja się powtórzyła. W tym jednak przypadku tok prac nie został jedynie spowolniony, ale odłożony ad acta. Dopiero w roku 1936 udało się zlikwidować ten jaskrawy przykład nierówności prawa wyborczego.

Zapowiadana w preambule do ustawy z 1911 roku dalsza reforma Izby Lordów w kierunku nadania jej bardziej demokratycznej podstawy nie została przeprowadzona. Katalog przyczyn tego stanu rzeczy przedstawił David Shell. Zwracał on uwagę na wewnętrzną transformację tej izby, co spowodowało zmianę punktu widzenia opinii publicznej, ale i niechętnej izbie wyższej części klasy politycznej. Wyzbyła się ona stopniowo dawnych grzechów: braku kompetencji, chaosu w organizacji obrad, powszechnego lenistwa. Przestała - w przeważającej liczbie przy- 
padków - przeszkadzać legislacji izby niższej, a z czasem zaczęła konstruktywnie ją uzupełniać (Shell, 2007, s. 112). Były też i inne przyczyny. Dwie wojny światowe, kryzysy gospodarcze, nowe wyzwania cywilizacyjne - wszystko to musiało zepchnąć kwestie reformy Izby Lordów na dalszy, a czasem bardzo odległy plan. Wypada jednak zaznaczyć, że problematyka reformowania Izby Lordów powracała co jakiś czas, niekiedy nawet efektywnie, na forum debaty publicznej i jest ona tam obecna również na początku XXI wieku.

\section{Bibliografia:}

Bryant, Ch. (2014). Parliament. The Biography, Vol. 2. Cambridge: Black Swan Publishing.

Danel, Ł. (2014). Izba Lordów w parlamentaryzmie brytyjskim. Warszawa: Wydawnictwo Sejmowe.

Grzybowski, K. (1946). Demokracja angielska. Warszawa: Czytelnik.

Hill, B. (1996). The Early Parties and politics 1688-1832. Basingstoke MacMillan.

Jaeschke, A. (2013). Metamorfozy parlamentu westminsterskiego do potowy XVIII wieku. Kraków: Wydawnictwo Naukowe Uniwersytetu Pedagogicznego.

Jaeschke, A. (2017). Metamorfozy parlamentu westminsterskiego. Od potowy XVIII do końca XIX wieku. Kraków: Wydawnictwo Naukowe Uniwersytetu Pedagogicznego.

Jennigs, T.A. (1996). Parliament, Party and Politics in Victorian Britain. Manchester: University Press.

Kędzierski, J. (1986). Dzieje Anglii. 1485-1939, t. 2. Wrocław: Zakład Narodowy im. Ossolińskich.

Koranyi, K. (1967). Powszechna historia państwa i prawa, t. 4. Warszawa: PWN.

Lang, S. (1999). Parliamentary Reform 1785-1928. Abington: Routledge.

Lyon, A. (2003). Constitutional History of the United Kingdom. London-Sydney-Portland: Cavendish Publishing.

Maurois, A. (1957). Dzieje Anglii. Warszawa: KiW.

Mckenzie, K. (1968). The English Parliament. London: Penguin.

Norton, F. (2013). Parliament in British Politics. London: Palgrave Macmillan.

Parker, R. (2013). British Prime Ministers. Stroud: Amberley Publishing.

Rallings, K., Thrasher, M. (2007). British Electoral Facts 1832-2006. London: Ashgate Publishing.

Shell, D. (2007). The House of Lords. Manchester: University Press.

Smith, E.A. (1992). The House of Lords in British Politics and Society. 1815-1922. London-New York: Longman.

Sobolewski, M. (1997). Partie i systemy partyjne świata kapitalistycznego. Warszawa: PWN. Trevelyan, G.M. (1965). Historia Anglii. Warszawa: PWN. 